\title{
LOCAL CONDITIONS OF PRODUCTION AND ECONOMIC DISAGRARIZATION OF FARMS
}

Tomasz WOJEWODZIC, Institute of Economic and Social Sciences, Department of Economics and Organization of Agriculture, Faculty of Agriculture and Economics, University of Agriculture in Krakow, Aleja Adama Mickiewicza 21, 33-332 Kraków, Poland, rrtwojew@cyf-kr.edu.pl

Wojciech SROKA, Institute of Economic and Social Sciences, Department of Economics and Organization of Agriculture, Faculty of Agriculture and Economics, University of Agriculture in Krakow, Aleja Adama Mickiewicza 21, 33-332 Kraków, Poland, w.sroka@ur.krakow.pl

Aleksandra PLONKA, Institute of Economic and Social Sciences, Department of Economics and Organization of Agriculture, Faculty of Agriculture and Economics, University of Agriculture in Krakow, Aleja Adama Mickiewicza 21, 33-332 Kraków, Poland, a.plonka@ur.krakow.pl (corresponding author)

Evolution of agrarian systems in countries with fragmented agricultural area structure leads to a decrease in the number of farms and an increase in the area and effectiveness of entities developing their activity. It is necessary to find out the causes of disagrarization - a process that is manifested at the macroeconomic level in reduced significance of agriculture in the national economy, among other things, and reduced importance of agricultural incomes in the economy of the countryside and a part of farms at the microeconomic level - in order to effectively impact ongoing changes that often affect the whole regions. The paper is an attempt to identify the factors determining the intensity of the process of the production and economic disagrarization of farms in Lesser Poland Voivodeship. Calculation procedures performed using the zero unitarization method and Data Mining tools enabled assessment of the intensity of the phenomenon analysed in the different territorial units (gminas), and identification of factors that have the biggest impact on its intensity. Using the process of modelling by the C\&RT method it has been found out that the characteristics that describe the agrarian structure historically, i.e. intensity of the organisation of agriculture, fragmentation of the agrarian structure, had a big impact on differentiation of gminas in terms of the intensity of disagrarization. High intensity of the organisation of agriculture combined with good environmental conditions is conducive to the retention of production functions of agriculture in a given area. With low intensity of the organisation of agriculture and very large fragmentation of the agrarian structure, the intensity of disagrarization was very often determined by characteristics typical of periurban areas or tourist attractions, i.e. increase in population density and increase in the number of residential buildings. Urban development of a given territorial unit stimulated processes of exiting agriculture.

Keywords: $C \& R T$, disagrarization, farm, urbanised areas

\section{INTRODUCTION}

With the economic development of regions and countries, the importance of the different sectors and branches of the economy is changing. At the same time, the significance and functions fulfilled by agriculture and agricultural production are becoming redefined. Food production, though it may seem an activity without an alternative, is increasingly taking place outside agriculture. Farms in Poland have been largely transformed from food producers into producers of raw materials of agricultural origin, with non-production functions (social, environmental) already dominating in a part of them. What is increasingly pointed out is disagrarization of the countryside, or even disagrarization of entities that function as farms in legal terms, e.g. through payment of agricultural tax or benefiting from area payments. The current processes of disagrarization are manifested in a decreased importance of agriculture in the economy of individual families, towns and the country.

\section{RESEARCH METHODS}

The aim of the paper has been to assess the intensity of the process of production-related and economic phenomenon. Production-related and economic disagrarization should be understood as reduction of the scale, or abandonment, of agricultural activity and related limitation of the significance of agricultural income in the incomes of households of agricultural landowners.

The intensity of disagrarization of farms in gminas of Lesser Poland voivodeship has been assessed using a synthetic indicator built on the basis of three standardised characteristics:

- intensity of the organisation of agriculture $\mathrm{Io}_{2010}$,

Copyright (C) 2017 The Authors. Published by Aleksandras Stulginskis University. This is an open-access article distributed under the terms of the Creative Commons Attribution License (CC-BY 4.0), which permits unrestricted use, distribution, and reproduction in any medium, provided the original author and source are credited. 
- percentage of households with a landowner that derive income from agricultural activity (\%),

- share of farmland maintained in a good agricultural condition in the area of farms' agricultural land (\%).

All the three variables were explanatory variables showing negative correlation with the response variable, i.e. their high value indicated low intensity of disagrarization, which made it possible to use one unitarization formula in the calculation process (1):

where:

$$
Z_{i j}=\frac{\max _{i} x_{i j}-x_{i j}}{\max _{i} x_{i j}-\min _{i} x_{i j}}
$$

$x_{i j}$ - value of explanatory variable $X_{j}$ in object $O_{i}$

max $x_{i j}$ - maximum value of explanatory variable in the examined population of objects

min $x_{i j}$ - minimum value of explanatory variable in the examined population of objects

$Z_{i j}$ - standardised value of explanatory variable $X_{i j}$

Synthetic assessment of the level of disagrarization for a given gmina was an arithmetical mean of standardised variables. Lesser Poland voivodeship was selected as the area to be covered by the research due to, among other things, the relatively high population density of this area, which places it among regions that are most urbanised and characterised by high changeability of environmental and economic conditions of carrying out agricultural production.

For identification of the most important determinants of the intensity of the process of production-related and economic disagrarization of farms, the C\&RT method (software Statistica ${ }^{1}$ ) has been used, and the quality control of the results obtained has been conducted using v-fold cross validation $(v=10)$ (Sroka, Dacko 2010). CART is a binary decision tree algorithm capable of processing continuous or categorical predictor or target variables. It works recursively: data is partitioned into two subsets to make the records in each subset more homogeneous than in the previous subset; the two subsets are then split again until the homogeneity criterion or some other stopping criteria is satisfied (Breiman et al., 1984, Delen et al., 2013). The classification process starts at the root node (which encompasses the entire dataset) and ends at the terminal nodes. In choosing the best splitter, the program seeks to maximize the average "purity" of the two child nodes (Speybroeck et al., 2004). The traditional recursive partitioning approaches of CART use empirical entropybased measures, such as the Gini gain or the information gain, as split selection criteria (Strobl et al., 2007). A detailed description of the method used can be found, among other things, in the study by Dębska and Guzowska-Świder (2011).

Due to the fact that the dependent variable (DezAgr) was quantitative in character and was described on a ratio scale, it was converted into a qualitative variable described on an ordinal scale. For that purpose, a quartile division was used:

- gminas with low intensity of disagrarization (quartile I),

- gminas with moderate intensity of disagrarization (quartiles II and III),

- gminas with very high intensity of disagrarization (quartile IV).

The set of explanatory values was created based on the resources of mass statistics (BDL GUS) and data from the Agency for Agriculture Restructuring and Modernisation. It included indicators the quantification of which was possible in all the gminas examined ${ }^{2}$.

\section{The location theory and processes occurring in rural areas}

The quality and organisation of agricultural production space and its location relative to supply and sales points have a significant impact on the character of the activity conducted and economic benefits derived from it. These issues have been often described in academic literature over almost two centuries by Ricardo (1817), von Thünen (1826), George (1879), Jonasson (1925) and Sinclair (1967), among others. Modern-day observations of the distribution of agricultural production do not clearly show regularities in this area. Localisation, social, economic and environmental factors overlap, making research more difficult (Wojewodzic 2017). The scale and character of agricultural activity, and often also the reduction or abandonment of production, are determined by the possibility of realisation of various types of rents, which are very often combined. Such rents may have various sources, such as the quality of land (differential rent I), possibility of production intensification (differential rent II), location relative to markets (differential rent III), quality of the environment (differential rent IV). Apart from those mentioned above, other economic rents may also be realised, including settlement, construction, planning rents (Marks-Bielska 2010). Due to the increasing importance of public transfers for the activity of private entities, institutional rents are actively sought (Tullock 1967, Czyżewki 2013). Institutional rents include a landowner's special benefits resulting from the use of an agricultural land (e.g. area payments) and from the fact of having a farmer's status (payment of lower contributions to mandatory social insurance, tax reliefs and exemptions) (Wojewodzic 2017).

A rent that significantly reduces the processes of land concentration in areas with a fragmented agrarian structure, often leading to a set-aside of a part of lots, is a capital rent, which arises, among other things, from increasing land prices. Landowners in suburban zones or in the vicinity of industrial zones very unwillingly decide to sell their assets, expecting a further increase in prices and realisation of a higher capital rent in the future (Ciaian and Kancs 2012, Musiał and Wojewodzic 2014). Realisation of land-related rents has an important impact both on the pace and scope of the processes of agrarian structure reorganisation and the intensity of the process of disagrarization.

\footnotetext{
${ }^{1}$ STATISTICA ${ }^{\circledR}$, data analysis software system, version 12. StatSoft, Inc. 2014.

${ }^{2}$ The description of selected indicators will be presented further in the paper (Table 1).
} 


\section{RESEARCH FINDINGS}

Lesser Poland voivodeship is an area with a very large differentiation of economic and environmental conditions, including topography. Cracow remains an important supra-regional economic centre, while Tarnów and Nowy Sącz are dynamically developing economic centres. Economic processes in this territory are also largely affected by the vicinity of Silesian agglomeration, which is particularly visible in the western part of the voivodeship. Due to high average population density (around 224 person/ $/ \mathrm{km}^{2}$ ), almost twice as high as for the whole country $\left(123\right.$ person $/ \mathrm{km}^{2}$ ), these areas are among the most urbanised ones, and if we add their huge economic potential and agrarian fragmentation, they are among those at the highest risk of countryside disagrarization. The relatively large share of land that is in a poor agricultural condition in the area of farms, which ranges from $0.8 \%$ to $61.7 \%$ in different gminas, and low intensity of agriculture organisation, which in $91.2 \%$ of gminas should be regarded as extensive or not very intensive ${ }^{3}$, among other things, indicate intensified processes of disagrarization. As the research has shown, gminas with low intensity of the process of the production-related and economic disagrarization of farms were mainly located in the northern part of the voivodeship (Proszowice powiat, Miechów powiat and Dąbrowa powiat). The territorial units with the largest intensity of the phenomenon under examination were located in the southern, south-western and western parts of the region, mainly in Sucha, Olkusz, Myślenice and Nowy Sącz powiats. For the identification of the main determinants of the observed differentiation, the method of classification trees was used with a set of quantifiable characteristics describing the agrarian structure of the area examined, location of the different gminas relative to economic centres and selected parameters of the economic development (Tab. 1).

Table 1. Characteristics of predictors applied in the modelling process

\begin{tabular}{|c|c|c|c|}
\hline Name & $\begin{array}{l}\text { Symbol } \\
\text { in the tree diagram }\end{array}$ & $\begin{array}{l}\text { Variation } \\
\text { range }^{\text {a) }}\end{array}$ & $\begin{array}{l}\text { Importance from } \\
\text { the perspective of } \\
\text { CART results }\end{array}$ \\
\hline \multicolumn{4}{|c|}{ Selected parameters of agrarian structure in historical period (2002) } \\
\hline Percentage of farms with area $<5$ ha of agricultural land $2002(\%)$ & $\begin{array}{l}\text { farms from } 1 \text { to } 5 \text { ha of } \\
\text { agricultural land ' } 02\end{array}$ & $\begin{array}{l}34.5 \\
98.8\end{array}$ & 0.92 \\
\hline $\begin{array}{l}\text { Number of farms with area }>15 \text { ha per } 1000 \text { ha of agricultural } \\
\text { land } 2002 \text { (in units) }\end{array}$ & $\begin{array}{l}\text { farms over } 15 \text { ha of } \\
\text { agricultural land ' } 02\end{array}$ & $\begin{array}{c}0.0 \\
11.4\end{array}$ & 0.50 \\
\hline Number of tractors per 1000 ha of agricultural land 2002 (in units) & number of tractors ' 02 & $\begin{array}{c}0.0 \\
247.5\end{array}$ & 0.40 \\
\hline Intensity of the organization of agriculture Io 2002 (in points) & $\mathrm{I}_{\mathrm{o}}{ }^{\prime} 02$ & $\begin{array}{c}49.9 \\
366.4\end{array}$ & 1.00 \\
\hline \multicolumn{4}{|c|}{ Selected parameters of agrarian structure in dynamic terms 2005-2013 } \\
\hline Change of area covered by area subsidies in $2005-2013(\%)$ & $\begin{array}{l}\text { change of area JPO '05- } \\
\text { '13 }\end{array}$ & $\begin{array}{c}-46.9 \\
21.9\end{array}$ & 0.62 \\
\hline $\begin{array}{l}\text { Change in the number of beneficiaries of area payments in } 2005 \text { - } \\
2013(\%)\end{array}$ & beneficiaries JPO '05-'13 & $\begin{array}{l}-46.7 \\
-2.0\end{array}$ & 1.00 \\
\hline \multicolumn{4}{|l|}{$\begin{array}{ll} & \text { Location } \\
\end{array}$} \\
\hline Distance from Cracow $(\mathrm{km})$ & km to Krakow & $\begin{array}{c}10 \\
141\end{array}$ & 0.20 \\
\hline Economic distance from Cracow - speed of car (minutes) & time to Krakow & $\begin{array}{c}20 \\
168\end{array}$ & 0.24 \\
\hline Direct access to national road or expressway ${ }^{\text {b) }}$ & national roads & $\begin{array}{l}0-\text { no } \\
1-\text { yes }\end{array}$ & 0.26 \\
\hline $\begin{array}{l}\text { Neighborhood with a city with a population of over } 50 \text { thousand } \\
\text { b) }\end{array}$ & city $>50000$ & $\begin{array}{l}0-\text { no } \\
1-\text { yes }\end{array}$ & 0.11 \\
\hline Location of the municipality in the metropolitan area Cracow b) & metropolitan area & $\begin{array}{l}0-\text { no } \\
\text { I zone } \\
\text { II zone }\end{array}$ & 0.10 \\
\hline $\begin{array}{l}\text { Evaluation of valorisation of agricultural production space } \\
\text { (points) }\end{array}$ & WRPP & $\begin{array}{c}31 \\
102 \\
\end{array}$ & 0.66 \\
\hline \multicolumn{4}{|c|}{ Selected parameters of economic development } \\
\hline Change in the number of residential buildings in $2008-2013(\%)$ & $\begin{array}{l}\text { residential buildings '08- } \\
\text { '13 }\end{array}$ & $\begin{array}{l}-21.4 \\
29.1\end{array}$ & 0.34 \\
\hline $\begin{array}{l}\text { Average number of unemployed persons in the years } 2003-2013 \\
\text { per } 1000 \text { people in working age }\end{array}$ & unemployed '03-'13 & $\begin{array}{c}32.1 \\
159.2\end{array}$ & 0.28 \\
\hline Total migration balance 2005-2013 (per 1000 inhabitants) & migration '05-'13 & $\begin{array}{c}-60 \\
237.6\end{array}$ & 0.40 \\
\hline Change in population density in 2003-2013 (persons $/ \mathrm{km}^{2}$ ) & $\begin{array}{l}\text { residential buildings '08- } \\
\text { '13 }\end{array}$ & $\begin{array}{l}-7.3 \\
33.4\end{array}$ & 0.46 \\
\hline $\begin{array}{l}\text { Change in the number of economic entities per } 1000 \text { people in } \\
\text { working age in } 2005-2013 \text { (in units) }\end{array}$ & unemployed '03-'13 & $\begin{array}{l}-26.6 \\
59.3\end{array}$ & 0.39 \\
\hline
\end{tabular}

Source: own elaboration.

\footnotetext{
${ }^{3}$ In the assessment of the intensity of the organisation, the scale proposed by Kopec [1978] was used: extensive agriculture $(<200$ points), not very intensive (200-250 points).
} 
The research has shown that the factors with the biggest impact on the intensity of disagrarization in 2010 mainly included the historical characteristics of the agrarian structure (the year 2002), i.e. intensity of the organisation of agriculture, fragmentation of agrarian structure and changes in the number of beneficiaries of area payments that to some extent resulted from the first two. Among the localisation factors, a very important role was played by valorisation of agricultural production space (WRPP). Of much less significance than originally expected, were parameters describing the location relative to regional economic centres, which are very important in the concepts of regional development (see Satoła 2013).

The historical intensity of agricultural economy turned out to be the first and most important criterion differentiating gminas in terms of the intensity of the production-related and economic disagrarization of farms (fig. 1). A low scale of the phenomenon under examination was mainly observed in units with high score in the intensity of agriculture organisation (Io $>225.3$ points) and low intensity of processes of farm liquidation (fewer than $13.3 \%$ of farms resigned from area payments).

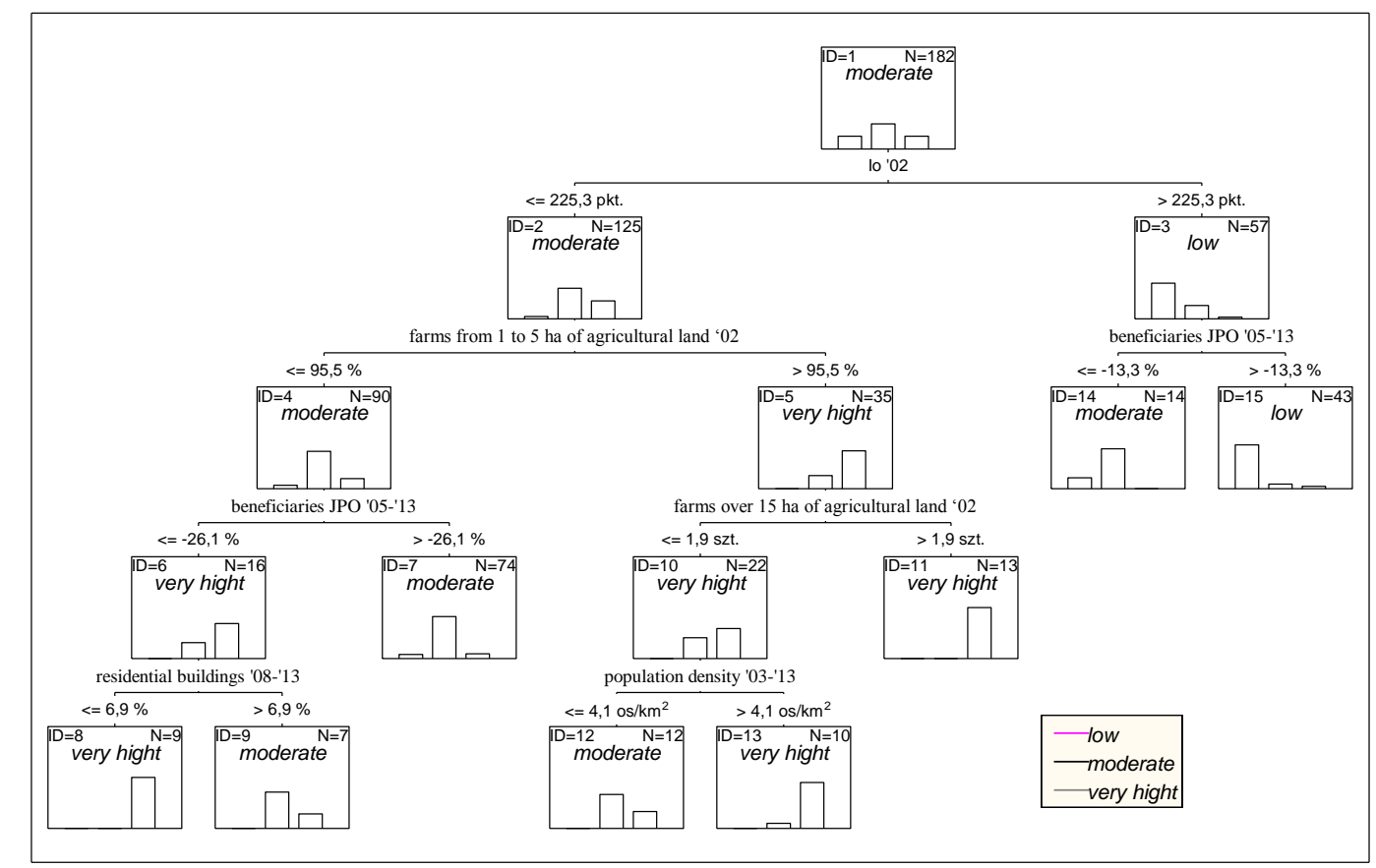

Source: own elaboration.

Figure 1. Interactive C\&RT classification tree for variable: intensity of productive and economic disagrarization of farms

The research has shown that territorial units that are most at risk of disagrarization are those where the relatively low intensity of agricultural organisation is accompanied by:

- a very large fragmentation of the agrarian structure (the share of small farms in the area structure is bigger than $95.5 \%$ ) together with an increase in population density (growth by more than 4,1 person $/ \mathrm{km}^{2}$ ),

- numerous cases of liquidation of farms (change in the number of SAPS beneficiaries in the period under analysis $>26.1 \%$ ) and a rapid growth of the number of residential buildings.

In both cases, it is worth stressing the importance of the factors indicating urbanisation pressure, which accompany a flawed agrarian structure.

\section{SUMMARY AND CONCLUSIONS}

The calculation procedures carried out based on the research have shown a relatively low intensity of the production-related and economic disagrarization in gminas located in the northern part of Lesser Poland Voivodeship and a very high one in gminas situated in the southern and western part. Using the process of modelling by the C\&RT method, it has been found out that the differentiation of gminas in terms of the intensity of disagrarization was greatly affected by the characteristics that describe the agrarian structure historically, and in the case of a large fragmentation of the agrarian structure - also by the urbanisation pressure. High intensity of the organisation of agriculture, combined with good environmental conditions, facilitate the retention of the production functions of agriculture in a given area. With a low intensity of the organisation of agriculture and very large fragmentation of the agrarian structure, the intensity of disagrarization was often determined by characteristics typical of periurban areas or tourist attractions, i.e. increase in population density and increase in the number of residential buildings.

\section{ACKNOWLEDGEMENT}

The publication was prepared as part of the research project "Urban agriculture as a challenge to sustainable development of metropolitan areas in Poland - socio-economic, environmental and planning aspects", financed by NCN, agreement no: 2016/21/D/HS4/00264. 


\section{REFERENCES}

1. Breiman, L., Friedman, J. H., Olshen, R. A., Stone, C. J. 1984. Classification and regression trees. Wadsworth \& Brooks. Monterey, CA.

2. Ciaian, P., D'Artis, K. 2012. The capitalization of area payments into farmland rents: micro evidence from the new EU member states. Canadian Journal of Agricultural Economics, Vol. 60, Iss. 4, pp. 517-540. 7. https://doi.org/10.2307/140568

3. Czyżewski, B. (editor). 2013. Renty ekonomiczne w gospodarce żywnościowej w Polsce, Polskie Wydawnictwo Ekonomiczne, Warszawa. [In Polish]

4. Delen, D., Kuzey, C., Uyar, A., 2013. Measuring firm performance using financial ratios: A decision tree approach. Expert Systems with Applications, Vol. 40, Iss. 10, pp. 3970-3983. https://doi.org/10.1016/j.eswa.2013.01.012

5. Dębska, B., Guzowska-Świder, B., 2011). Decision trees in selection of featured determined food quality. Analytica Chimica Acta, Vol. 705(1), pp. 261-271. https://doi.org/10.1016/j.aca.2011.06.030

6. George, H. 1879. Progress and poverty: an enquiry into the cause of industrial depressions, and of increase of want with increase of health, The Remedy, K. Paul, Trench \& Company.

7. Jonasson, O. 1925. Agricultural regions of Europe. Economic Geography, Vol. 1, Iss. 3, pp. $277-314$. https://doi.org/10.2307/140568

8. Kopeć B. 1978. Systemy gospodarcze w rolnictwie polskim, Powszechne Wydawnictwo Rolnicze i Leśne, Warszawa. [In Polish]

9. Marks-Bielska, R. 2010. Rynki ziemi rolniczej w Polsce - uwarunkowania i tendencje rozwoju, Wydawnictwo Uniwersytetu Warmińsko-Mazurskiego, Olsztyn. [In Polish]

10. Musiał, W., Wojewodzic, T. 2014. Bariery przemian agrarnych w rolnictwie polskim - poszukiwanie rozwiązań innowacyjnych [in:] Czyżewski, A., Klepacki, B. 2014. Problemy rozwoju rolnictwa i gospodarki żywnościowej w pierwszej dekadzie członkostwa Polski w Unii Europejskiej. Polskie Wydawnictwo Ekonomiczne, Warszawa. [In Polish]

11. Ricardo, D. 1817. On foreign trade. Principles of political economy and taxation, Prometheus Books. [In Polish]

12. Satoła, Ł. 2013. Zróżnicowanie wykorzystania funduszy Unii Europejskiej w układzie centrum - peryferia. Prace Naukowe Uniwersytetu Ekonomicznego we Wrocławiu, Gospodarka Przestrzenna, No. 320, pp. 176-185. [In Polish]

13. Sinclair, R. 1967. Von Thünen and urban sprawl. Annals of the Association of American Geographers, Vol. 57, Iss. 1, pp. $72-87$. https://doi.org/10.1111/j.1467-8306.1967.tb00591.x

14. Speybroeck, N., Berkvens, D., Mfoukou-Ntsakala, A., Aerts, M., Hens, N., Van Huylenbroeck, G., Thys, E., 2004. Classification trees versus multinomial models in the analysis of urban farming systems in Central Africa. Agricultural Systems, Vol. 80, No. 2, pp. 133-149. https://doi.org/10.1016/j.agsy.2003.06.006

15. Sroka, W., Dacko, M. 2010. Ocena czynników rozwoju przodujących gospodarstw rolniczych z wykorzystaniem metody drzew regresyjnych typu C\&RT. Zagadnienia Ekonomiki Rolnej, Vol. 2, pp. 100-112. [In Polish]

16. Strobl, C., Boulesteix, A. L., Augustin, T., 2007. Unbiased split selection for classification trees based on the Gini index Computational Statistics \& Data Analysis, Vol. 52, Iss. 1, pp. 483-501. https://doi.org/10.1016/j.csda.2006.12.030

17. Tullock, G. 1967. The welfare costs of tariffs, monopolies, and theft. Western Economic Journal, Vol. 5, Iss. 3, pp. $224-232$. https://doi.org/10.1111/j.1465-7295.1967.tb01923.x

18. Von Thünen, J. H. 1826. Der isolierte Staat in Beziehung auf Nationalökonomie und Landwirtschaft. Gustav Fischer, Stuttgart (reprinted 1966). [In Germany]

19. Wojewodzic, T. 2017. Procesy dywestycji i dezagraryzacji na obszarach o rozdrobnionej strukturze agrarnej. Zeszyty Naukowe Uniwersytetu Rolniczego im. H. Kołłątaja w Krakowie 535 (412). [In Polish] 